Biology-Botany

\title{
Cacti of Santa Maria - RS, Brazil
}

\author{
Cactos de Santa Maria, RS, Brasil \\ Igor Wassiljew Moial(iD, Guilherme Moreira da Silva"ID, Liliana Essi"ID \\ ' Universidade de São Paulo, São Paulo, SP, Brazil \\ "Universidade Federal de Santa Maria, Santa Maria, RS, Brazil
}

\begin{abstract}
A floristic survey of the Cactaceae family was carried out in the municipality of Santa Maria, Brazil, which is localized in the central region of Rio Grande do Sul state. The study was conducted between August 2017 and November 2018, during which time 14 species were recorded. Five species are on the endangered species list of Rio Grande do Sul. The threatened species are Echinopsis oxygona (Link) Zucc. Ex. Pfeiff. \& Otto, Parodia horstii (F. Ritter) N.P. Taylor, Parodia glaucina (F. Ritter), Hofacker \& M. Machado, Parodia linkii (Lehm.), R. Kiesling, and Parodia ottonis (Lehm.) N. P. Taylor. This paper presents a complete list of the species with reference to conservation status.
\end{abstract}

Keywords: Cactaceae; Floristic survey; Endangered species; Fragmentation; Hotspot

\section{RESUMO}

Um levantamento florístico da família Cactaceae foi realizado no município de Santa Maria, Brasil, localizado na região central do estado do Rio Grande do Sul. O estudo foi realizado entre agosto de 2017 e novembro de 2018, período em que foram registradas 14 espécies. Um total de cinco espécies está na lista de espécies ameaçadas de extinção do Rio Grande do Sul. As espécies ameaçadas são Echinopsis oxygona (Link) Zucc. Ex. Pfeiff. \& Otto, Parodia horstii (F. Ritter) N.P. Taylor, Parodia glaucina (F. Ritter), Hofacker e M. Machado, Parodia linkii (Lehm.), R. Kiesling e Parodia ottonis (Lehm.) N. P. Taylor. Este artigo apresenta uma lista completa de espécies e referência ao seu estado de conservação.

Palavras-chave: Cactaceae; Levantamento florístico; Espécies ameaçadas; Fragmentação; Hotspot 


\section{INTRODUCTION}

There are approximately 1,438 species within Cactaceae, which are distributed among approximately 127 genera (HUNT et al., 2006). With many life forms, plants such as the epiphytic cacti from the genus Lepismium Pfeiff and Epiphyllum Haw are found growing on trees. Rupicule plants are found growing on rocks, and many species from the genus Parodia Speg. have become successfully established on rocky terrain (CARNEIRO et al., 2016). In addition, cacti grow in a wide range of soil types. For instance, Echinopsis oxygona (Link) Zucc. Ex. Pfeiff \& Otto are found growing in rocky soils, while Opuntia monacantha (Willd.) Haw. may be found growing in sandy soils (CARNEIRO et al., 2016). According to Goettsch et al. (2015), and as evaluated by the International Union for Conservation of Nature (IUCN), Cactaceae is the angiosperm Family with the greatest number of threatened species, totaling $31 \%$ of the 1478 species. The Cactaceae family is divided into four subfamilies: Pereskioideae, Maihuenioideae, Opuntioideae and Cactoideae, the latter of which is the most diverse, with seven tribes and around 1,222 species (HUNT et al., 2006; ORTEGA-BAES et al., 2010). It is is restricted to the Americas, with the exception of the Rhipsalis baccifera (J.S. Muel) Stern., which also occurs in continental Africa, Madagascar and Sri Lanka (HUNT et al., 2006). As Barthlott (1983) states, the distribution of $R$. baccifera was likely driven by birds. In America, the distribution of the Cactaceae family spans a significant distance from Canada to Patagonia, in South America, demonstrating an impressive diversity of species and habitats that vary from arid deserts to tropical forests (ANDERSON, 2001).

The main diagnostic characteristic for the family is the presence of areoles, structures that may be described as a short shoot or as a highly specialized axillary bud, from which new vegetative branches, spines and flowers develop (GIBSON and NOBEL, 1986). The spines themselves have a high taxonomic value in the family (BENSON, 1979), being found in the middle or on the periphery of the areoles, varying in number, color, shape and consistency from species to species. The 
flowers are monoclamid, usually arising from the modified branch apexes and may solitary or arranged in multiple inflorescences. The perigonium is constituted by tepals, typically with sepal-like outer parts and petal-like inner parts. The stamens are numerous, and the ovary position is inferior or half-inferior, being constituted by three or more carpels gathered in a single pistil (CARNEIRO et al., 2016).

In Brazil, there are 38 genera and 288 native species of Cactaceae (ZAPPI and TAYLOR, 2020). As demonstrated by Mizrahi et al. (1997), cacti have a potentially significant economic value. They can be used as forage plants to feed cattle, as is the case in Northeast Brazil (SILVA et al., 2005), where Xique-xique [Pilosocereus gounellei (F.A.C.Weber) Byles \& Rowley], are used in dairy cows' alimentation. Additional important ethnobotanic uses for this family's species include human alimentation, and the construction of doors and windows using its wood (LIMA, 1996). In addition, some species are used as forage plants, which may have medicinal purposes. For example, Mandacaru (Cereus jamacaru DC.) roots are used in the treatment of urinary tract infections and renal diseases, and the parenchyma of many species of the genus Melocactus Link \& Otto, can be used to treat cough, flu and bronchitis (AGRA, 1996; ANDRADE et al., 2006). According to Zappi et al. (2011), the conservation of the Cactaceae family has been negatively impacted by illegal commerce and collection. Genera such as Parodia Speg. and Frailea Britton \& Rose in Rio Grande do Sul, are highly sought after by local and international collectors. Furthermore, the continuous fragmentation of habitats that include Caatinga, Atlantic Forest and Restinga significantly threaten cacti biodiversity. The colonial history of Restinga has made it one of the most endangered habitats, because historically, it was undermined by intense agricultural activity and urbanization, and currently, it is being further impacted by the construction of highways, resorts, and other forms of development. The rupicule species have been particularly affected by mining activities, because the plants of this species often grow in rocky areas, and suffer significant damage during the extraction 
process. Mining is extremely harmful to plant life and is one of the largest threats to the Cactaceae family (ZAPPI et al., 2011).

In Rio Grande do Sul, according to Carneiro et al. (2016), there are 11 genera and 65 species of Cactaceae, which correspond respectively to $28,2 \%$ and $24.07 \%$ of all the country's diversity. A total of 53 of 65 species and seven of 11 genera are threatened (SEMA-RS, 2014).

The objective of this study is to conduct a floristic survey of the Cactaceae species from Santa Maria municipally, Rio Grande do Sul, Brazil. The Cactaceae family form the focus of this study due to the richness of documented species for Rio Grande do Sul (CARNEIRO et al., 2016) and the lack of data on the region of Santa Maria, since there is only one extensive study about Santa Maria's Flora until now (BELTRÃO, 1962). Furthermore, according to Longhi et al. (2000), a significant section of native forest from the region has suffered anthropic alteration due to the use of the land for the purposes of agricultural and urban development. These facts justify the necessity of studies that focus on the local biodiversity of this family.

\section{MATERIAL AND METHODS}

\subsection{Study area}

Santa Maria municipality is located in the central region of Rio Grande do Sul state, Brazil, between the parallels $29^{\circ} 43^{\prime} 57^{\prime \prime S}$ and $29^{\circ} 55^{\prime} 30^{\prime \prime} S$ and the meridians $53^{\circ} 42^{\prime} 13^{\prime \prime} \mathrm{W}$ and $53^{\circ} 48^{\prime} 02^{\prime \prime} \mathrm{W}$ (Figures 1 and 2), with a territory of approximately 178 000 hectares. According to Alvares et al. (2013), the county is in the temperate climatic range and has the characteristics of Subtropical climate type Cfa. According to climate classification of Köppen, therefore, the county has a humid subtropical climate. As a result, the study area is marked by the predominance of intense summers and well-distributed rains throughout the year, whose thermal averages vary between $17^{\circ} \mathrm{C}$ and $19^{\circ} \mathrm{C}$ (PEREIRA et al., 1989). The average temperature of 
the hottest month, January, is $24.8^{\circ} \mathrm{C}$ and the coldest month, July, is $14.1^{\circ} \mathrm{C}$. The average annual precipitation of the study area is 1,769 mm/year (LONGHI et al., 2000).

Figure 1 - Map of the location of the study site

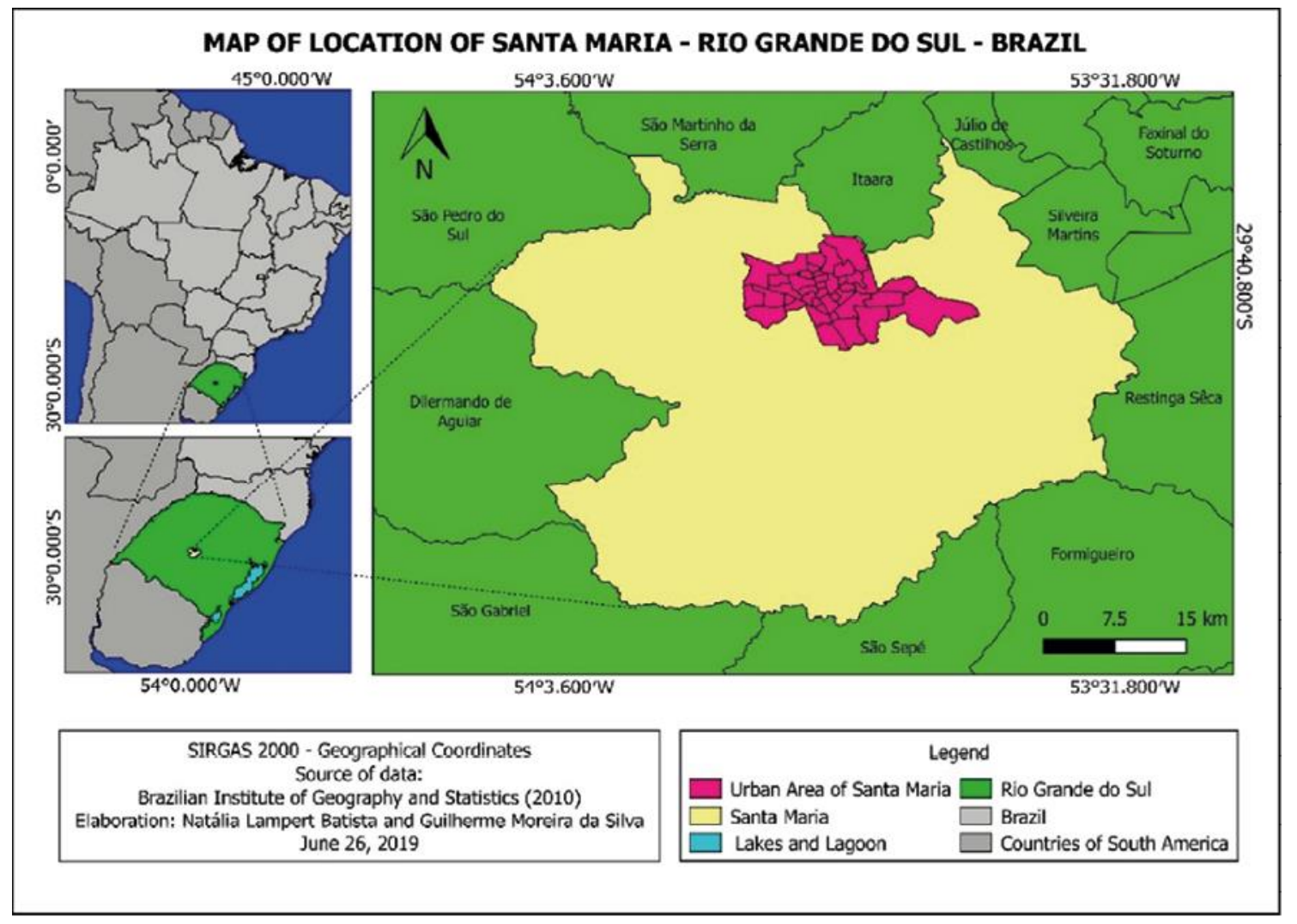

According to the classifications established by Reitz et al. (1988), Santa Maria is located in the Central Depression, which means that it is characterized by low and/or slightly undulating terrain and the buttresses that form the Serra Geral. This geomorphological region is characterized by the presence of valleys and hills, resulting from the morphogenetic processes of a dry climate in the past, and a humid climate in the present. The region is also a transition zone between the biomes of the Pampa and the Atlantic Forest, which results in a significant level of both vegetal and animal biodiversity (PILLAR et al., 2009). The municipality has two main vegetal formations: Pampa Grassland and Seasonal Deciduous Forest. Pampa 
grassland generally lacks trees or bushes and instead consists of a thin layer of herbaceous plants, primarily grasses. In contrast, the seasonal deciduous forested areas in the Atlantic Forest have dense vegetation cover that consists of large trees, epiphytic species, and other features (PILLAR et al., 2009). In relation to the lithostratigraphic units, the Santa Maria region is characterized by the predominance of sedimentary rocks, followed by smaller numbers of volcanic rocks from the Paraná Basin. Thus, the municipality covers the lithologies corresponding to the Southern Rosary, Santa Maria, Caturrita, Botucatu and Serra Geral Formations (SARTORI, 2009).

Figure 2 - Maps of the districts of Santa Maria

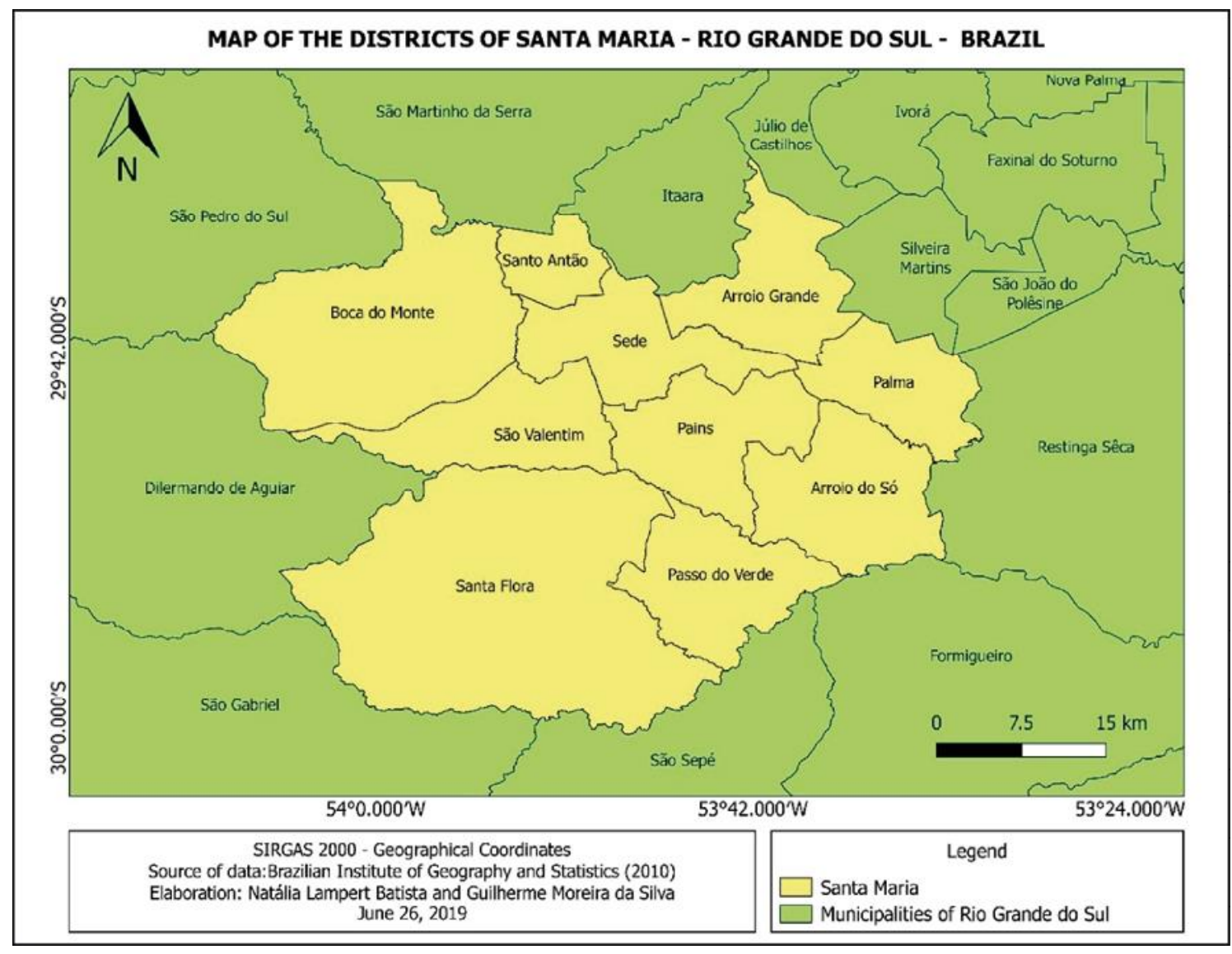

\subsection{Floristic survey}

Five field expeditions were carried out between August 2017 and November 2018. In order to maximize the efficiency of the expeditions, the random walking 
method proposed by Filgueiras et al. (1994) was used for sampling. The expeditions covered the main sites in which Cactaceae occurred, including rocky cliffs, rocky outcrops, rocky and sandy soils, and forested areas. Previously sampled plants were also consulted in the SMDB and HDCF herbariums (acronym according to THIERS [continuously updated]) and speciesLink online portal (http://www.splink.org.br/index?lang=pt).

The identification and herborization activities were carried out in the Plant Taxonomy Laboratory of Santa Maria Federal University. When necessary, plant identification was carried out by consulting family keys and Cactaceae experts. The methodology proposed by Groot (2011) informed the herborization process, as specific to Cactaceae.

Voucher specimens were incorporated to the SMDB herbarium and the species names' were verified by consulting the TROPICOS (online botanical database) and Flora of Brazil 2020 website (ZAPPI and TAYLOR, 2020). Threat category of the species were verified by consulting SEMA-RS (2014) and Goettsch et al. (2015). Authorization for collecting plants was given by ICMBio (47962). The access to Brazilian Genetic Heritage is recorded in SISGEN system under the number A3ADA3D.

\section{RESULTS AND DISCUSSION}

A total of 14 native species were recorded and were found to be distributed across three subfamilies, four tribes and seven genera. The most diverse subfamily was Cactoideae (11 species), followed by Opuntioideae (two species) and Pereskioideae (one species). In Cactoideae, the most diverse tribes were Rhipsalideae (five species), which was followed by Notocacteae (four species), Cereeae (one species) and Trichocereeae (one species). The list of species is presented in Table 1. 
Table 1 - List of species identified in this survey, ordered by subfamily and tribe. Vouchers, habit and habitat are presented for each species. Precise geographical coordinates are not provided for the endangered species. The habit and habitat are described according to observations in the study sites

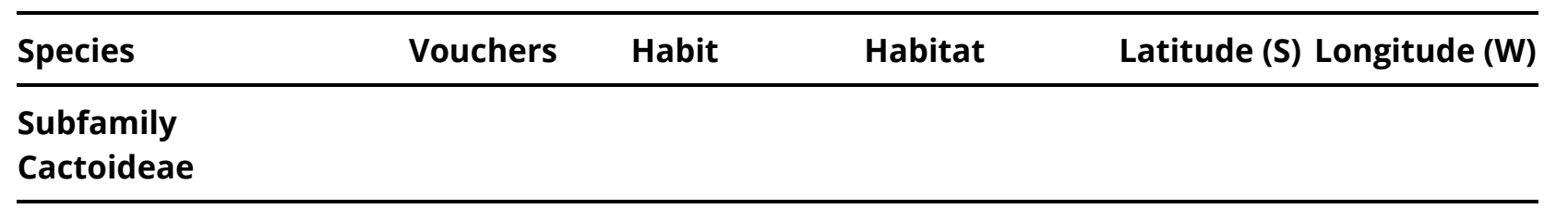

Tribe Cereeae

\begin{tabular}{|c|c|c|c|c|c|}
\hline $\begin{array}{l}\text { Cereus } \\
\text { hildmannianus K. } \\
\text { Schumam (Fig } \\
\text { 3D,E,F) }\end{array}$ & $\begin{array}{l}\text { Essi, L. (1273) } \\
\text { (SMDB 18383) }\end{array}$ & $\begin{array}{l}\text { Tree or } \\
\text { climbi } \\
\text { ng } \\
\text { shrub }\end{array}$ & $\begin{array}{l}\text { Sandy and rocky soils, } \\
\text { rock outcrops and } \\
\text { rocky cliffs }\end{array}$ & $29^{\circ} 38^{\prime} 11.3^{\prime \prime}$ & $53^{\circ} 54^{\prime} 29.9$ \\
\hline
\end{tabular}

\section{Tribe Notocacteae}

\section{Parodia horstii (F.} Ritter) N.P. Taylor

Eggli, U. (2475)

(PACA 73465)

Parodia glaucina (F. Ritter) Hofacker \& M. Machado (Fig. 5E)

Moia, I.W. (14)

et al. (SMDB 18062)

Parodia linkii (Lehm.)

R. Kiesling (Fig. 5D)

Parodia ottonis

(Lehm.) N. P. Taylor

(Fig. 5F, G)

Moia, I.W. (12)

(SMDB 18061)

Registred by photography
Herb

Herb

Herb

Herb

Rock outcrops, sandy
and rocky soils.

$29^{\circ} 39^{\prime} 25.97$

"

$53^{\circ} 50^{\prime} 50.08^{\prime \prime}$

\section{Tribe Rhipsalideae}

Lepismium cruciforme

(Vell.) Miq. (Fig. 4F,G)

Lepismium

houlletianum (Lem.)

Barthlott (Fig. 4E)

Lepismium

lumbricoides (Lem.)

Barthlott (Fig. 4C, D)

Lepismium

warmingianum $(\mathrm{K}$.

Schum.) Barthlott

(Fig. 3A)
Moia, I.W. (17) Epiphy et al. (SMDB tic 18381) herb

$\begin{array}{cc}\text { Wolf, K. (31) } & \text { Epiphy } \\ \text { (SMDB 15231) } & \text { tic } \\ \text { herb }\end{array}$

Moia, I.W. (09) Epiphy et al. (SMDB 17221)
Moia, I.W. (16) Epiphy et al. (SMDB tic 18380) herb

\section{Forests}

$29^{\circ} 40^{\prime} 26.5^{\prime \prime}$

$53^{\circ} 43^{\prime} 16.7^{\prime \prime}$

Forests

$29^{\circ} 34^{\prime} 00.0^{\prime \prime}$

$53^{\circ} 41^{\prime} 00.0^{\prime \prime}$

Forests, forest borders and on roadside trees

$29^{\circ} 46^{\prime} 40.7^{\prime \prime} \quad 54^{\circ} 51^{\prime} 36.5^{\prime \prime}$

Forests $29^{\circ} 40^{\prime} 30.8^{\prime \prime}$ $53^{\circ} 43^{\prime} 07^{\prime \prime}$ 
Table 1 - Conclusion

\begin{tabular}{|c|c|c|c|c|c|}
\hline Species & Vouchers & Habit & Habitat & $\begin{array}{l}\text { Latitude } \\
\text { (S) }\end{array}$ & $\begin{array}{l}\text { Longitude } \\
\text { (W) }\end{array}$ \\
\hline
\end{tabular}

\section{Subfamily}

Cactoideae

\section{Tribe Rhipsalideae}

\begin{tabular}{lccccc}
\hline Echinopsis oxygona & Moia, I.W. (18) & Herb & Rock outcrops and & $29^{\circ} 39^{\prime 25.97}$ & 53०50'50.08" \\
(Link) Zucc. Ex. Pfeiff. & et al. (SMDB & or & rocky soils. & $"$ & \\
\& Otto (Fig. 5A, B, C) & 18382) & shrub & &
\end{tabular}

\section{Subfamily}

\section{Pereskioideae}

\begin{tabular}{|c|c|c|c|c|c|}
\hline $\begin{array}{l}\text { Pereskia aculeata } \\
\text { Mill. (Fig. 4A) }\end{array}$ & $\begin{array}{c}\text { Rau, G (SMDB } \\
175)\end{array}$ & $\begin{array}{l}\text { Climbi } \\
\text { ng } \\
\text { shrub } \\
\text { and } \\
\text { shrub }\end{array}$ & Forest areas & $\begin{array}{c}\text { Not } \\
\text { informed }\end{array}$ & $\begin{array}{c}\text { Not } \\
\text { informed }\end{array}$ \\
\hline
\end{tabular}

\section{Subfamily \\ Opuntioideae}

\begin{tabular}{|c|c|c|c|c|c|}
\hline $\begin{array}{l}\text { Opuntia elata Link \& } \\
\text { Otto ex Salm- Dyck } \\
\text { (Fig. 3B) }\end{array}$ & $\begin{array}{l}\text { Wolf, S (218) } \\
\text { (SMDB 16770) }\end{array}$ & Shrub & $\begin{array}{l}\text { Rock outcrops and } \\
\text { rocky soils. }\end{array}$ & $29^{\circ} 34^{\prime} 00.0^{\prime \prime}$ & $53^{\circ} 41^{\prime} 00.0^{\prime \prime}$ \\
\hline $\begin{array}{l}\text { Opuntia monacantha } \\
\text { (Willd.) Haw. } \\
\text { (Fig. 3C) }\end{array}$ & $\begin{array}{l}\text { John, A.L.W. } \\
\text { (SMDB 18.063) }\end{array}$ & Shrub & Sandy soils & $29^{\circ} 41^{\prime} 20,5^{\prime \prime}$ & $53^{\circ} 42^{\prime} 34,2^{\prime \prime}$ \\
\hline
\end{tabular}

Many species were found in forested areas, where they were recorded as growing or climbing on trees. Species including Lepismium cruciforme, L. warmingianum, Rhipsalis teres and Pereskia aculeata (Figures 3 and 4), were found and collected both within the forest and on the outskirts of forested areas, growing or climbing on trees of varying heights. The conservation status for these species is Least Concern (LC). 
Figure 3 - A. Lepismium warmingianum. B. Opuntia elata. C. Opuntia monacantha. D-F. Cereus hildimannianus

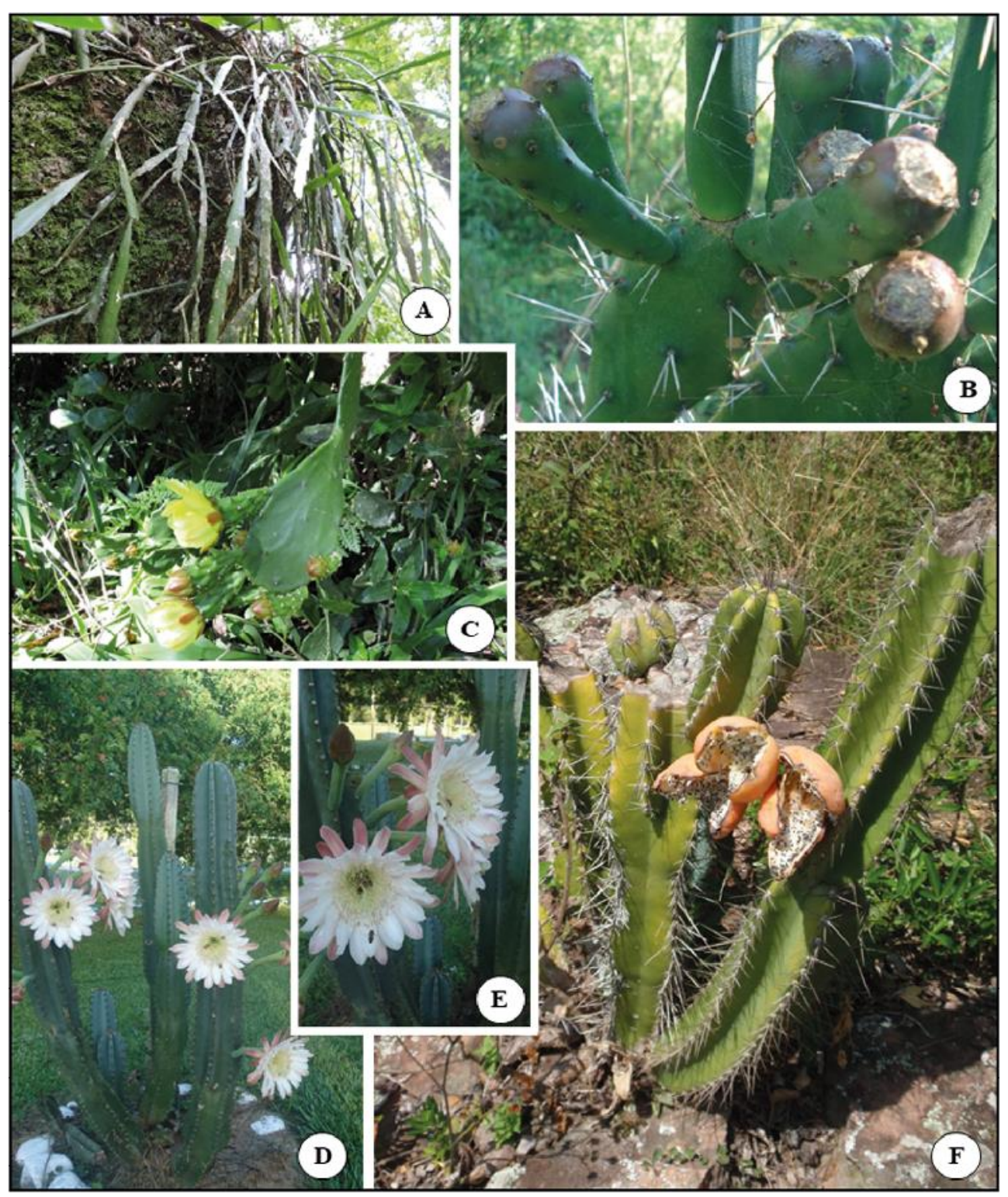

Even though Echinopsis oxygona (Figure 5. A-C) conservation status, according to Goetsch et al. (2015) is LC in a world-wide context, in Rio Grande do Sul, this species is Vulnerable (VU). Several species of the genus Parodia were also found. Parodia glaucina, according to SEMA-RS (2014), is currently in Endangered (EN) conservation status; $P$. horstii is in EN conservation status; $P$. linkii, according Goettsch et al. (2015) is LC in a world-wide context, while for Rio Grande do Sul, it is VU. Parodia ottonis (Figure 5. F-G) is considered VU. All the threatened species 
were found on rocky areas such as rocky cliffs and the nearby rocky sites, usually surrounded by significant grasslands.

Figure 4 - A. Pereskia aculeata. B. Rhipsalis teres. C-D. Lepismium lumbricoides. E. Lepismium houlletianum. F-G. Lepismium cruciforme

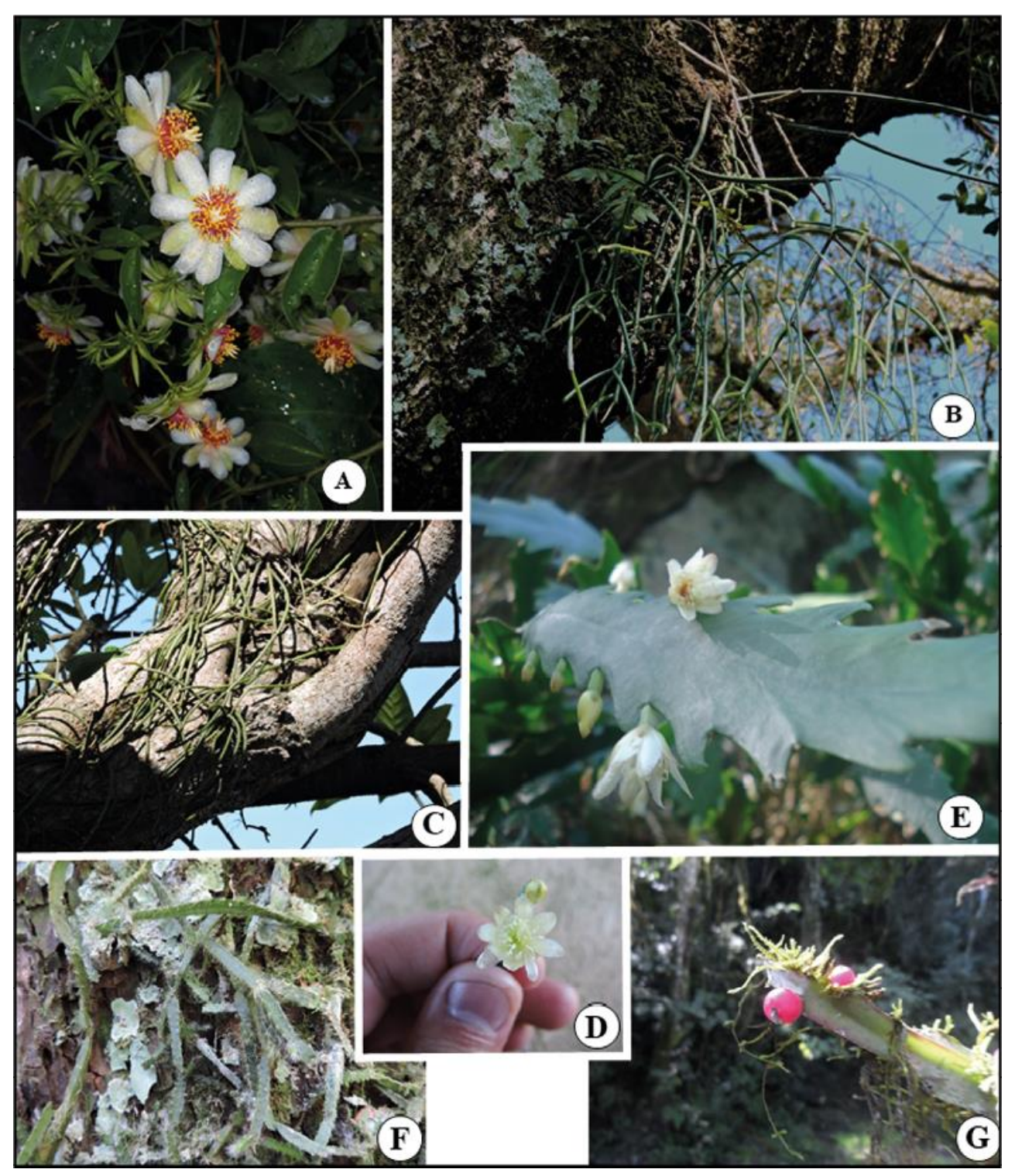

Concerning Parodia glaucina, cited in the work of CARNEIRO et al. (2016) (Figure 5. E), a recent taxonomic revision (ANCESCHI and MAGLI, 2018) considered this species as a heterotypic synonym for Parodia ottonis. There are not references to this name in the official list of Parodia from Brazil so far (ZAPPI and TAYLOR, 2020), and this name is not indexed in important international databases like 
TROPICOS, or THE PLANT LIST (http://www.theplantlist.org/), however this name is very common in identifications in herbaria specimens in the state of Rio Grande do Sul. Since this name is mentioned in the official list of endangered species of Rio Grande do Sul, we opted to maintain the citation of this species, as a distinct taxon, by now.

Figure 5 - A-C. Echinopsis oxygona. D. Parodia linkii; E. Parodia glaucina. F-G. Parodia ottonis

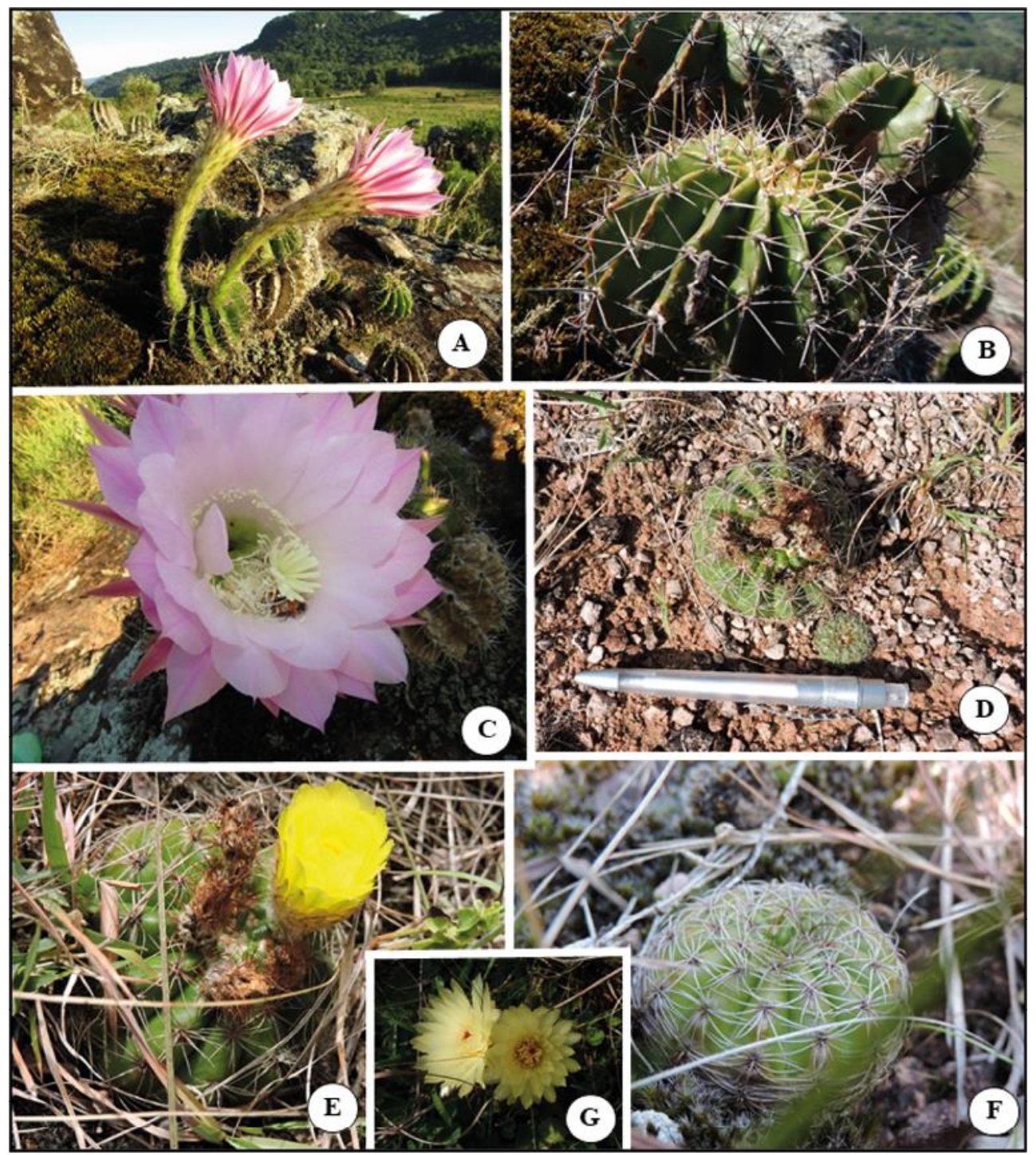


Other species including Cereus hildmannianus K. Schumam, Opuntia elata (as presented by CARNEIRO et al., 2016) and O. monacantha were found on both rocky sites and on roadsides. The conservation status for these plants is LC.

The fact that a high proportion (five of 14 , or $35.71 \%$ ) of the native Cactaceae species are threatened is concerning. It is even more concerning that Rio Grande do Sul, alongside with Uruguay, represents the biggest hotspot for threatened cacti species (GOETTSCH et al., 2015). For this reason, the precise geographical coordinates of the most threatened species were not listed. Importantly, this study also discovered that all of the threatened Cactaceae species were found in rocky outcrops. This suggests that kind of places are home to significant and differentiated biodiversity, particularly since it is also known that families such as Asteraceae and Fabaceae also have a number of species concentrated within similar conditions (MENEZES and ESSI, 2016; SCHAEFER and ESSI, 2017).

\section{ACKNOWLEDGEMENTS}

The authors thank the FIPE fellowship (UFSM), granted for the first author, and thank Marlon C. Machado as well, assisting with the identification of Parodia.

\section{REFERENCES}

AGRA MF. Plantas da medicina popular dos Cariris Velhos, Paraíba, Brasil. Editora União, João Pessoa; 1996. Pp. 125.

ALVARES CA, STAPE JL, SENTELHAS PC, GONÇALVES JLM, SPAROVEK G. Köppen's climate classification map for Brazil. Meteorologische Zeitschrift. 2013; 22: 711-728.

ANCESCHI G, MAGLI A. A synopsis of the genus Parodia Spegazzini s.l. (Cactaceae). Bradleya. 2018; 36:70-161.

ANDERSON EF. The Cactus Family. Oregon, Timber Press Portland; 2001.

ANDRADE CTS, MARQUES JGW, ZAPPI DC. Utilização de cactáceas por sertanejos baianos. Tipos conexivos para definir categorias utilitárias. Sitientibus. Série Ciências Biológicas. 2006; 6: 3 - 12. 
BARTHLOTT W. Biogeography and evolution in Neo- and Paleotropical Rhipsalinae (Cactaceae). In Proc. Int. Symp. Dispersal and Distribution. Edited by K. Kubitzki. Sonderbd. naturwiss. Ver. Hamburg. 1983; 7: 241-248.

BELTRÃO R. Flórula fanerogâmica do município de Santa Maria. Boletim do Instituto de Ciências Naturais da Universidade Federal de Santa Maria. 1962; (1): 1-63.

BENSON L. Plant Classification. Second edition. Lexington, Massachusetts: D. C. Heath; 1979.

CARNEIRO AM, FARIAS-SINGER R, RAMOS RA, NILSON AD. Cactos do Rio Grande do Sul - Porto Alegre, Fundação Zoobotânica; 2016.

FILGUEIRAS TS, NOGUEIRA PE, BROCHADO AL, GUALA GF. Caminhamento: um método expedito para levantamentos florísticos qualitativos. Cadernos de Geociência. 1994; 12: 39-43.

GIBSON AC, NOBEL PS. The Cactus Primer. Harvard University Press, Cambridge. 1986.

GOETTSCH B, HILTON-TAYLOR C, CRUZ-PIÑON G, DUFFY JP et al. High proportion of cactus species threatened with extinction. Nature Plants. 2015; 1: Article number: 15142. http://dx.doi.org/10.1038/nplants.2015.142

GROOT SJ De. Collecting and processing cacti into herbarium specimens, using ethanol and other methods. Systematic Botany. 2011; 36: 981-989.

HUNT DR, TAYLOR NP, CHARLES G. The new cactus lexicon - Milborn Port, Text. Dh Publications. 2006.

LIMA JLS de. Plantas forrageiras das caatingas - usos e potencialidades. Petrolina, EMBRAPACPATSA, PNE, RBGKEW; 1996. 37p.

LONGHI SJ, ARAUJO MM, KELLING MB, HOPPE JM, MÜLLER I, BORSOI GA. Aspectos fitossociológicos de fragmento florestal de floresta estacional decidual, Santa Maria, RS. Ciência Florestal, Santa Maria. 2000; 10(2): 59-74.

MENEZES HFD, ESSI L. Leguminosas campestres do Morro Pedra do Lagarto, Santa Maria, Rio Grande do Sul, Brasil. Balduinia. 2016; (55): 21-31. http://dx.doi.org/10.5902/2358198024711

MIZRAHI Y, NERD A, NOBEL PS. Cacti as Crops. Horticultural Review. New York. 1997; 18(1): 291 320.

ORTEGA-BAES P, SÜHRING S, SAJAMA J, SOTOLA E, ALONSO-PEDANO M, BRAVO S, GODÍNEZALVAREZ H. Diversity and Conservation in the Cactus Family. In: Ramawat K. (eds) Desert Plants. Springer, Berlin, Heidelberg. 2010. http://dx.doi.org/1010.1007/978-3-642-02550-1_8

PEREIRA PRB, NETTO LRG, BORIN CJA, SARTORI MGB. Contribuição à geografia física do município de Santa Maria: unidades de paisagem. Geografia - Ensino \& Pesquisa. 1989; 3:3768. http://dx.doi.org/10.5902/2236499423884 
PILLAR VP, MÜLLER SC, CASTILHOS ZMS, JACQUES AVA. Campos Sulinos - conservação e uso sustentável da biodiversidade - Brasília, Ministério do Meio Ambiente. 2009.

REITZ R, KLEIN RM, REIS A. Projeto madeira do Rio Grande do Sul. Porto Alegre: Secretaria da Agricultura e Abastecimento. 525 p. 1988.

SARTORI, PLP. Geologia e geomorfologia de Santa Maria. In: História natural de Santa Maria. Ciência e Ambiente, Santa Maria. 2009; 1 (38): 19-42.

SCHAEFER J, ESSI L. A checklist of Asteraceae from Pedra do Lagarto, Santa Maria, Rio Grande do Sul, Brazil. Check List. 2017; 13 (6):1075-1090. https://doi.org/10.15560/13.6.1075.

SEMA-RS (Secretaria de Meio Ambiente do Rio Grande do Sul). Assembleia Legislativa do Estado do Rio Grande do Sul. Decreto Estadual n 52.109/2014. Espécies da Flora nativa ameaçadas de extinção do estado do Rio Grande do Sul. 2014. Available from: http://www.al.rs.gov.br/filerepository/repLegis/arquivos/DEC\%2052.109.pdf. Accessed on: 2019-02-20.

SILVAJGM, SILVA DS, FERREIRA MA, LIMA GFC, MELO AAS, DINIZ MCNM. Xiquexique (Pilosocereus gounellei) (A. Weber ex K. Schum.) Bly. ex Rowl. em Substituição à Silagem de Sorgo (Sorghum bicolor L. Moench) na Alimentação de Vacas Leiteiras. R. Bras. Zootec. 2005; 34 (4): 1408-1417.

THIERS, B. [continuously updated]. Index Herbariorum: a global directory of public herbaria and associated staff. New York Botanical Garden's Virtual Herbarium. Available from: http://sweetgum.nybg.org/science/ ih/.

TROPICOS [internet]. Missouri Botanical Garden. Available from: http://www.tropicos.org/NameSearch.aspx. Accessed on: 2019-03-09.

ZAPPI D, TAYLOR N, MACHADO M, SANTOS MR. Ameaças. In: Ribeiro-Silva, S. et al. (Orgs.) Conservação das Cactaceae no Brasil. Plano de ação nacional para a conservação das cactáceas.- Brasília : Instituto Chico Mendes de Conservação da Biodiversidade, ICMBio. (Série Espécies Ameaçadas, 24). 2011.

ZAPPI D, TAYLOR N. Cactaceae in Flora do Brasil 2020 em construção. Jardim Botânico do Rio de Janeiro. Available from: http://floradobrasil.jbrj.gov.br/reflora/floradobrasil/FB70. Accessed on: 24 Ago. 2020. 


\section{Authorship Contribution}

\section{1 - Igor Wassiljew Moia}

Mestrando em Ciências Biológicas,

https://orcid.org/0000-0002-9447-7584 - igor_moia@hotmail.com

Contribution: Conceptualization; Methodology; Investigation; Data curation; Writing original draft; Writing - review \& editing

\section{2 - Guilherme Moreira da Silva}

Laboratório de Cartografia, Centro de Ciências Naturais e Exatas

https://orcid.org/0000-0003-2613-7139 - guilhermems2010@gmail.com

Contribution: Visualization; Writing - review \& editing

\section{3 - Liliana Essi}

Docente do Programa de Pós-Graduação em Agrobiologia, http://orcid.org/0000-0001-5548-6448 - liliana.essi@ufsm.br

Contribution: Conceptualization; Methodology; Investigation; Data curation; Project administration; Writing - review \& editing

\section{How to quote this article}

MOIA, I. W.; SILVA, G. M. S.; ESSI, L. Cacti of Santa Maria - RS, Brazil. Ciência e Natura, Santa Maria, v. 43, e23, p. 1-16, 2021. DOI 10.5902/2179460X39827. Available from: https://doi.org/10.5902/2179460X39827. Accessed: Month Abbreviated. day, year. 